BUDGETING : Journal of Business, Management and Accounting

Volume 1, Nomor 1, Desember 2019

e-ISSN: 2715-2480

p-ISSN: 2715-1913

DOI : https://doi.org/10.31539/budgeting.v1i1.797

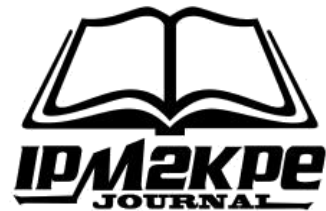

\title{
DAMPAK ALOKASI DANA DESA, JUMLAH WAJIB PAJAK, JUMLAH PENDUDUK DAN LUAS LAHAN TERHADAP REALISASI PENERIMAAN PBB-P2
}

\author{
Halimatus Sa'diyah ${ }^{1}$, Diyah Probowulan ${ }^{2}$, Achmad Syahfrudin $Z^{3}$ \\ Universitas Muhammadiyah Jember ${ }^{1,2,3}$ \\ Halimatussadiyah15407@gmail.com ${ }^{1}$
}

\begin{abstract}
ABSTRAK
Penelitian ini bertujuan untuk mengetahui pengaruh dampak alokasi dana desa, jumlah wajib pajak, jumlah penduduk dan luas lahan terhadap realisasi pendapatan PBB-P2 di Kabupaten Jember secara parsial. Penelitian ini merupakan penelitian kuantitatif dengan menggunakan metode penelitian survei. Populasi penelitian ini adalah semua desa di Kabupaten Jember, sampel berjumlah 44 desa dengan penerimaan PBB-P2 yang telah memenuhi target. Pengambilan sampel menggunakan teknik purposive sampling. Data dikumpulkan melalui data sekunder dari studi literature dan dokumentasi penerimaan realisasi pajak daerah. Analisa data menggunakan regresi linear berganda. Hasil penelitian variabel alokasi dana desa, didapatkan nilai signifikan $0,006<0,05$, yang berarti bahwa Alokasi Dana Desa secara parsial berdampak signifikan terhadap realisasi penerimaan PBB-P2. Variabel Jumlah Wajib Pajak memiliki nilai signifikan 0,000 $<0,05$ yang berarti memikiki dampak secara signifikan terhadap realisasi penerimaan PBB-P2. Variabel Jumlah penduduk dengan nilai $0,000<0,05$ memberikan makna memiliki dampak secara signifikan realisasi penerimaan PBB-P2. Variabel Luas lahan dengan nilai sig. $0,000<0,05$, dapat diartikan memiliki memiliki dampak secara signifikan terhadap Pendapatan PBB-P2. Simpulan semakin banyak luas lahan yang dimanfaatkan oleh penduduk, ditambah jumlah penduduk dan jumlah wajib pajak memiliki dampak mempengaruhi secara signifikan peningkatan realisasi penerimaan PBB-P2, begitu juga dengan jumlah Alokasi Dana Desa Berpengaruh dan berdampak signifikan pada peningkatan realisasi penerimaan PBB-P2.
\end{abstract}

Kata Kunci : Alokasi Dana Desa, Jumlah Wajib Pajak, Populasi, Luas Lahan, Penerimaan PBB-P2

\begin{abstract}
This study aims to partially determine the effect of the impact of Village Fund Allocation, Population and Land area on the Realization of PBB-P2 Revenue in Jember Regency. This research is a quantitative study using survey research methods. The population of this study was all villages in Jember Regency, the sample was 44 villages with PBB-P2 acceptance that met the target. Sampling using a purposive sampling technique. Data was collected through secondary data from literature studies and documentation of local tax revenue realization. Data analysis uses multiple linear regression. The results of the Village Fund Allocation research variable, obtained a significant value of $0.006<0.05$, which means that the Village Fund Allocation partially has a significant impact on the realization of $P B B-P 2$ revenue. The variable number of taxpayers has a significant value of 0,000 $<0.05$ which means it has a significant impact on the realization of PBB-P2 revenue. Variable Number of population with a
\end{abstract}


value of 0,000<0.05 means that it has a significant impact on the realization of $P B B$ $P 2$ revenue. Variable land area with sig. 0,000 <0.05, can be interpreted as having a significant impact on PBB-P2 Revenue. Conclusion The more land area utilized by the population, plus the number of residents and the number of taxpayers has a significant impact on increasing the realization of $P B B-P 2$ revenue, while the amount of Village Fund Allocation has a partially significant impact on the realization of PBB-P2 revenue

Keywords: Village Fund Allocation, Number of Taxpayers, Population, Land Area, Acceptance of Rural and Urban Land and Building Taxes

\section{PENDAHULUAN}

Pajak merupakan modal utama untuk membiayai aktivitasi pemerintah dalam menjalankan serta melaksanakan pembangunan. Sebagian besar penerimaan negara adalah berasal dari pajak sehingga pajak sangat berperan dalam pembangunan suatu negara (Rahmawati, 2008). Maka fungsi pajak adalah berkaitan erat dengan alat kerja pemerintah untuk menyejahterakan negaranya dalam lingkup sumber daya manusia maupun dalam membangun sarana prasarana untuk menunjang kesejahteraan rakyatnya. Berkaitan dengan aktivitas pajak berperan dalam pembangunan, salah satu jenis pajak yang ikut serta dalam meningkatkan fungsi tersebut adalah pajak bumi dan bangunan (PBB) yaitu iuran wajib yang di kenakan terhadap orang atau badan yang secara nyata, mempunyai hak, memiliki, menguasai, dan memperoleh manfaat dari bumi dan bangunan (Rahman, 2011).

Undang-undang Nomor 23 Tahun 2014 tentang pemerintahan daerah menjadi landasan hukum bagi penambahan serta pengembangan otonomi daerah di Indonesia. Dengan adanya undang-undang tersebut, maka pemerintah daerah memiliki tugas dan tanggung jawab yang lebih untuk mengelola sumber dana yang diperoleh guna mengembangkan otonomi daerah yang dipimpin. Termasuk dalam pengelolaan Pajak Bumi dan Bangunan Perdesaan dan Perkotaan (PBB-P2), bentuk kebijakan tersebut tertuang dalam UU Nomor 28 Tahun 2009 tentang UU Pajak Daerah dan Retribusi Daerah (UU PDRD) (Abdullah, 2007).

Untuk mewujudkan otonomi daerah menjadi lebih baik maka dibutuhkan sinergisitas antara pemerintah daerah dan masyarakat guna mewujudkan otonomi daerah yang diharapkan. Masyarakat dalam konteks ini adalah penduduk yang bertempat tinggal di daerah tersebut. Konteks yang belangsung dalam hal ini adalah penerimaan pendapatan dan keuangan daerah yang berasal dari Pajak PBB-P2. 
Pemerintah daerah sebagai pihak otorisasi yang berwenang adalah sebagai ujung tombak dalam pemungutan pajak PBB-P2 agar penerimaaniPBB-P2 sesuai target yang ditetapkan.

Dalam memenuhi target yang ditetapkan oleh pemerintah dalam penerimaan PBB-P2, maka jumlah penduduk juga berpengaruh terhadap hal tersebut. Karena semakin banyak penduduk dalam suatu daerah, maka semakin banyak juga wajib pajak yang harus memenuhi kewajibannya dalam membayar pajak. Agar hasil penerimaan Pajak Bumi dan Bangunan dapat terealisasi sesuai target yang ditetapkan, perlu diketahuii faktor-faktor yang mempengaruhi penerimaan pengelolaan Pajak Bumi dan Bangunan.

Wajib Pajak Pajak Bumi dan Bangunan (PBB) adalah Subjek Pajak yangi dikenakan kewajiban membayar Pajak Bumi dan Bangunan.Pertumbuhan penduduki merupakan unsur penting yang dapat memacu pertumbuhan ekonomi suatu daerah. Penduduk yani besari akani menggerakkani berbagaii kegiatani ekonomii dani merangsangi tingkati outputi ataui produksii agregati yangi lebihi tinggii sertai padai akhirnyai mendorongi pertumbuhani ekonomi dani pendapatani nasional, yangi berpengaruhi jugai terhadapi peningkatani penerimaani Pajaki Bumi dani Bangunani (Cahyono, 2009).

Peningkatan pendapatan nasional tersebut akan menciptaka iwajib pajak baru, sehingga Cahyono (2009) menyimpulkan bahwa pertumbuha ipenduduk bila ditangani dengan serius, maka akan menambah jumlah wajib pajak yang membayar pajak. Tapi jika pertambahan penduduk tidak diikuti dengan peningkatan kualitas maka jumlah penduduk hanya akan menjadi beban Negara dan tidak akan menghasilkan atau menambah wajib pajak baru.

Alokasi Dana Desa merupakan salah satu bentuk hubungan keuangan antar tingkat pemerintahan yaitu hubungan keuangan antara pemerintahan kabupaten dengan pemerintahan desa. Untuk dapat merumuskan hubungan keuangan yang sesuai maka diperlukan pemahaman mengenai kewenangan yang dimiliki pemerintah desa (Wawan, 2017). Menurut Wawan (2017), penjabaran kewenangan desa merupakan implementasi program desentralisasi dan otonomi, dengan adanya desentralisasii dan otonomii desai maka desa memerlukan pembiayaan untuk menjalankan kewenangan yang dilimpahkani kepadanya. 
Pemberian Alokasi Dana Desa merupakan wujud dari pemenuhan hak desa untuk menyelenggaraka otonomi desa agar tumbuh dan berkembangi mengikuti pertumbuhan dari desa itu sendiri berdasarkan keanekaragaman, partisipasi, otonomi asli demokratisasi dan pemberdayaan masyarakat. Alokasi Dana Desa kiranya dapat meningkatkan pembangunan di desa, dengan meningkatnya pembangunan di desa penerimaan PBB akan meningkat karena masyarakat akan dapat melihat manfaat nyata dari pengeluaran yang digunakan untuk membayarkan pajak pada pemerintah pusat. Dalam Surat Pemberitahuan Pajak Terhutang (SPPT), dasar penetapan Nilai Jual Objek Pajak (NJOP) sangat bergantung kepada luas tanah.

Semakin besar luas tanah maka NJOP semakin tinggi sehingga penerimaan PBB juga semakin meningkat. Dengan adanya peningkatan jumlah luas lahan yang digunakan, maka penerimaan PBB pun juga akan mengalami kenaikan Kabupaten Jember merupakan Kabupaten di Jawa Timur yang telah melaksanakan pengalihan pengelolaan PBB-P2 pada tahun 2013. Setelah melakukan pengalihan PBB-P2, Kabupaten Jember melalui Dinas Pendapatan melakukan semua kegiatan perpajakan yang berkaitan dengan PBB-P2. Berikut data dari Dinas Pendapatan Kabupaten Jember menunjukan target dan realisasi penerimaan PBB-P2 Tahun 2013 - 2015.

Penelitian sebelumnya dilakukan oleh Febrianti (2017) yang berjudul faktorfaktor yang mempengaruhi realisasi penerimaan pajak bumi dan bangunan sektor pedesaan dan perkotaan di Kabupaten Bangka Tengah. Berdasarkan penelitian tersebut maka penulis tertarik untuk mengembangkan penelitian yang dilakukan oleh Febrianti (2017) namun dengan beberapa perbedaan antara lain yang pertama adalah dengan menambah variabel bebas lain yaitu alokasi dana desa. Hal ini berdasarkan hasil wawancara kecil yang peneliti lakukan dengan pihak yang berwenang terkait dengan penerimaan PBB-P2 bahwa pernah diterapkannya persyaratan harus lunas PBB-P2 setiap desa pada Tahun 2013 sebelum mencairkan alokasi dana desa. Dengan alasan tersebut, maka tidak menutup kemungkinan bahwa ADD juga berperan dalam peningkatan penerimaan PBB-P2 pada tahun 2011. Kedua, rentang waktu penelitian ini tahun 2011 - 2015 sehingga memperluas penelitian sebelumnya, dan ketiga penelitian ini menggunakan penelitian dalam bentuk survey dan metode yang digunakan dalam penelitian ini adalah penelitian yang bersifat verifikatif yaitu penelitian yang 
menggunakan penyajian jawaban dari hasil pemikiran yang kebenarannya bersifat sementara (hipotesis).

\section{KAJIAN TEORI}

\section{Target Pendapatan daerah}

Agar perkiraan pendapatan daerah dapat dipertanggung jawabkan didalam penyusunannya memerlukan perhitungan terhadap faktor-faktor sebagai berikut ; 1) Realisasi penerimaan pendapatan daerah dari tahun anggaran yang lalu dengan memperlihatkan factor pendukung yang menyebabkan tercapainya realisasi tersebut dan faktor-faktor yang menghambatnya; 2) Kemungkinan pencairan jumlah itu tunggakan tahun-tahun sebelumnya yang diperkirakan dapat ditagih minimal 35\% dari tunggakan sampai dengan tahun berlalu; 3) Data potensi obyek pajak dan estimasi perkembangan dan perkiraan pnerimaan dari penetapan tahun berjalan minimal $80 \%$ dari penetapan; 4) Kemungkinan adanya perubahan atau penyesuaian keseragaman dari dan penyempurnaan system pemungutan; 5) Keadaan sosial ekonomi dan tingkat kesadaran masyarakat selaku wajib pajak; 6) Perkembangan tersedianya sarana dan prasarana serta biaya pungutan.

\section{Pendapatan Asli Daerah}

Pendapatan Asli Daerah merupakan suatu pendapatan yang menunjukan kemampuan suatu daerah dalam menghimpun sumber-sumber dana untuk membiayai pengeluaran rutin. Jadi dapat dikatakan bahwa Pendapatan Asli Daerah sebagai pendapatan rutin dari usaha-usaha Pemerintah Daerah dalam memanfaatkan potensi potensi sumber keuangan daerahnya sehingga dapat mendukung pembiayaan penyelenggaraan Pemerintah dan pembangunan daerah.

Sumber Pendapatan Asli Daerah Pemerintah Daerah supaya dapat mengurus rumah tangganya sendiri dengan sebaik-baiknya, maka perlu diberikan sumber-sumber pembiayaan yang cukup. Tetapi mengingat bahwa tidak semua sumberi pembiayaan dapat diberikan kepada daerah maka daerah diwajibkan untuk menggali segala sumbersumber keuanganyai sendiri berdasarkan peraturan perundangi-undangan yangi berlaku. Undang-Undang No. 32 Tahun 2004 pasal 157 tentangi Pemerintah Daerah, menyebutkan sumber-sumber Pendapatan Asli Daerah adalah meliputi: pajak daerah, 
retribusi daerah, bagian laba badan usaha milik daerah, penerimaan dari dinas-dinas daerah, penerimaan lain-lain

\section{Alokasi Dana Desa}

Alokasi Dana Desa merupakan salah satu bentuk hubungan keuangan antar tingkat pemerintahan yaitu hubungan keuangan antara pemerintahan kabupaten dengan pemerintahan desa. Untuk dapat merumuskan hubungan keuangan yang sesuai makaidiperlukan pemahaman mengenai kewenangan yang dimiliki pemerintah desa (Wawan, 2017). Alokasi Dana Desa yang biasa disebut ADD merupakan wujud dari pemenuhan hak desa untuk menyelenggarakan otonominya agar tumbuh dan berkembang mengikuti pertumbuhan dari desa itu sendiri, iberdasarkan keanekaragaman, partisipasi, otonomi asli danipemberdayaan masyarakat. Bantuanilangsung ADD adalah dana bantuan langsung yang dialokasikan kepada pemerintah desa digunakan untuk meningkatkan sarana pelayanan masyarakat, kelembagaan dan prasarana desa yang diperlukan serta diprioritaskan oleh masyarakat, yang pemanfaatan dan administrasi pengelolaannya dilakukan dan dipertanggungjawabkan oleh kepala desai (Aljannah, 2017).

Adapun Tujuan pemberian bantuan langsung Alokasi Dana Desa (ADD) adalah; 1) Meningkatkan terselenggaranya pemerintahan desa dalam melaksanakan pelayanan pemerintahan terhadap masyarakat, pembangunan dan kemasyarakatan sesuai dengan wewenang yang berlaku; 2) Meningkatkan ikemampuan lembaga kemasyarakatan di desa dalam perencanaan, pelaksanaan dan pengendalian pembangunan secara partisipatif sesuai dengan potensi yang dimiliki; 3) Meningkatkan pemerataan pendapatan, kesempatan kerja dan kesempatan berusaha bagi masyarakat desa serta dalam rangka pengembangan kegiatan sosial ekonomi masyarakat; 4) Mendorong partisipasi serta gotong royong masyarakat.

Alokasi Dana Desa kiranya dapat meningkatkan pembangunan di desa, dengan meningkatnyai pembangunan di desa penerimaan PBB akan meningkat karena masyarakat akan dapat melihat manfaat nyata dari pengeluaran yang digunakani untuk membayarkan pajak pada pemerintah pusat. Dalam Surat Pemberitahuan Pajak Terhutang (SPPT), dasar penetapan Nilai Jual Objek Pajak (NJOP) sangat bergantung kepada luas tanah. Semakin besari luas tanah maka NJOP semakin tinggi sehingga 
penerimaan PBB juga semakin meningkat. Dengan adanya peningkatanijumlah luas lahan yang digunakan, maka penerimaan PBB pun juga akan mengalami kenaikan (Wawan, 2017).

\section{Jumlah Wajib Pajak}

Subyek Pajak Bumi dan Bangunan Sektor Perdesaan dan Perkotaan adalah orang pribadi atau yang secara nyata mempunyai suatu hak atas bumi dan atau memeperoleh manfaat atas bumi, dani atau mamiliki, menguasai, dan atau memperoleh manfaat atas bangunan. Subjekipajak yang dikenakan kewajiban untuk membayar pajak disebut juga wajib pajak, dan apabila suatu objek pajak belum jelas wajib pajaknya, maka kepala dinas pelayananan pajak atas nama gubernur dapat menetapkan subjek pajak sebagai wajib pajak. Wajibipajak adalah orang pribadi atau badan yang meliputi pembayar pajak, pemotong pajak dan pemungut pajak yang mempunyai hak dan kewajiban perpajakan sesuai dengan ketentuani dan juga peraturan perundang-undangan perpajakan daerah yang berlaku di daerah tersebut.

\section{Jumlah Penduduk}

Pertumbuhan penduduk merupakan unsur penting yang dapa imemacu pertumbuhan ekonomi suatu daerah. Penduduk yang besar akan menggerakkan berbagai kegiatan ekonomi dan merangsang tingkat output atau produksi agregat yang lebih tinggi serta pada akhirnya mendorong pertumbuhan ekonomi dan pendapatan nasional, yang berpengaruhipula terhadap peningkatan penerimaan Pajak Bumi dan Bangunan (Cahyono, 2009). Peningkatan pendapatan nasional tersebut akan menciptakan wajib pajak baru. Cahyono (2009) menyimpulkan bahwa pertumbuhan penduduk bila ditangani dengan serius akan menambah jumlah wajib pajak yang membayar pajak. Tapi jika pertambahan penduduk tidak diikuti dengan peningkatan kualitas maka jumlah penduduk hanya akan menjadi beban negara dan tidak akan menghasilkaniatau menambahiwajib pajak yang baru.

Untuk mewujudkan otonomi daerah menjadi lebih baik, maka dibutuhkan sinergisitas antara pemerintah daerah dan masyarakat guna mewujudkan otonomi daerah yang diharapkan. Masyarakat dalam konteks ini adalah penduduk yang bertempat tinggal di daerah tersebut. Konteks yang belangsung dalam hal ini adalah penerimaan pendapatan dan keuangan daerah yang berasal dari Pajak PBB-P2. 
Pemerintah daerah sebagai pihak otorisasi yang berwenangiadalah sebagai ujung tombak dalam pemungutan pajak PBB-P2 agar penerimaan PBB-P2 sesuai target yang ditetapkan. Dalam memenuhi target yang ditetapkan oleh pemerintah dalam penerimaan PBB-P2 maka jumlah penduduk juga berpengaruh terhadap hal tersebut. Karena semakin banyak penduduk dalam suatu daerah, maka semakin banyak pula wajib pajak yang harus memenuhi kewajibannya dalam membayar pajak sehingga penerimaan pajak khususnya PBB-P2 semakin meningkat.

\section{Luas Lahan}

Sebagaimana tercantum dalam Pasal 1 UU Pajak Bumi dan Bangunan, yang dimaksud dengan bumi adalah permukaan bumi, (perairan) dan tubuh bumi yang berada dibawahnya. Permukaani bumi itu sebetulnya tidak lain daripada tanah. Jadi yang menjadi objeki PBB itu adalah tanah (perairan) dan tubuh bumi. Untuk memudahkan penghitungani PBB yang terutang, tanah perlu diklasifikasikan (Rahman, 2010). Dalam penelitian ini, tingkat penerimaan PBB-P2 juga dipengaruhi oleh luas lahan karena semakin banyak luas lahan di suatu wilayah yang dapat digunakan untuk mendirikan bangunan, maka semakin tinggii dan banyak pula tingkat penerimaan PBB-P2 dan hal ini juga berhubungan terhadap realisasii penerimaan PBB-P2.

\section{METODE PENELITIAN}

Penelitian ini menggunakan jenis penelitian bersifat kuantitatif dan metode penelitian kausalitas. yaitu data yang dipakai adalah data penerimaan PBB-P2 yang diperoleh dari Badan Pendapatan Daerah Kabupaten Jember dan survei langsung terhadap objek yang akan diteliti. Data yang digunakan dalam penelitian ini adalah data sekunder. Ketersediaani data merupakan suatu hal yang mutlak dipenuhi dalam suatu penelitian ilmiah. Objek penelitian yang digunakan adalah penerimaan setiap desa yang berasal dari Pajak Bumi dan Bangunan Perkotaan dan Pedesaan (PBB-P2) pada tahun 2011 sampai tahun 2015.

Populasi dalam penelitian ini adalah seluruh desa di wilayah Kabupaten Jember, dengan sampel sebanyak 44 desa yang diambil menggunakan teknik Purposive sampling. Metode pengumpulan data menggunakan metode dokumentasi dan studi pustaka. Teknik Analisis Data menggunakan uji validitas, uji reliabilitasi dan uji 
normalitas. Sedangkan untuk uji asumsi klasik yang digunakan adalah uji multikolinearitas, uji heteroskedastisitas dan uji autokorelasi.

\section{HASIL PENELITIAN}

\section{Uji Parsial T}

Uji statistik t pada dasarnya menunjukkaniseberapa jauh pengaruh satu variabel penjelasan/independen secara individual dalam menerangkani variasi variabel dependen. Selanjutnya untuk menguji apakah variabel independen secarai individu atau parsial mempunyai pengaruh terhadap variabel dependen, makai digunakan uji t. hasil uji t adalah sebagai berikut :

Tabel 1

Hasil Uji t i

\begin{tabular}{lccccc}
\hline \multirow{2}{*}{ Variabel } & \multicolumn{5}{c}{ Uji t } \\
\cline { 2 - 5 } & $\begin{array}{c}\text { Signifikansi } \\
\text { Hitung }\end{array}$ & $\begin{array}{c}\text { Taraf } \\
\text { Sinifikansi }\end{array}$ & T Hitung & T Tabel & \\
\hline ADD (X1) & 0,006 & 0,05 & 2,769 & 1,97331 & Berdampak \\
\hline $\begin{array}{l}\text { Jumlah Wajib } \\
\text { Pajak (X2) }\end{array}$ & 0,000 & 0,05 & 11,056 & 1,97331 & Berdampak \\
\hline $\begin{array}{l}\text { Jumlah Penduduk } \\
(X 3)\end{array}$ & 0,000 & 0,05 & 8,903 & 1,97331 & Berdampak \\
\hline \begin{tabular}{l} 
Luas Lahani (X4) \\
\hline
\end{tabular} & 0,000 & 0,05 & 9,788 & 1,97331 & Berdampak \\
\hline
\end{tabular}

Sumber : Hasil Pengolahan SPSS v 21 (Data diolah 2019)

Berdasarkan nilai statistik hasil analisis pada tabel 5 dapat dilihat bahwa hasil uji parsial ADD (Alokasi Dana Desa) menunjukkan nilai t-hitung lebih besar dari ttabel $(2,769>1,97331)$ dengan signifikansi 0.006. Hal tersebut menunjukkan bahwa ADD (Alokasi Dana Desa) berdampak terhadap penerimaan PBB-P2. Nilai positif dalam t-hitung mengindikasikan bahwa terdapat hubungan yang positif. Hasil uji parsial jumlah wajib pajak menunjukkan nilai t-hitung lebih besar dari t-tabel (11,056 > 1,97331) dengan signifikansi 0.000 . Hal tersebut menunjukkan bahwa jumlah wajib pajak berdampak terhadap penerimaan PBB-P2. Nilai positif dalam t-hitung mengindikasikan bahwa terdapat hubungan yang positif. Dan hasil uji parsial jumlah penduduk menunjukkan nilai t-hitung lebih besar dari t-tabel i $(8,903>1,97331)$ dengan signifikansi 0.000 . 
Hal tersebut menunjukkan bahwa jumlah penduduk berdampak terhadap penerimaan PBB-P2. Nilai positif dalam t-hitung mengindikasikan bahwa terdapati hubungan yang positif. Serta berdasarkan nilai statistik hasil analisis pada tabel 4.8 dapat dilihat bahwa hasil uji parsial Luas Lahan menunjukkani nilai t-hitung lebih besar dari t-tabel $(9,788>1,97331)$ dengan signifikansi 0.000 . Hal tersebut menunjukkan bahwa Luas Lahan berdampak terhadap penerimaan PBB-P2. Nilai positif dalam thitung mengindikasikani bahwa terdapat hubungan yang positif.

\section{Uji Koefisien Determinasi ( $\mathbf{R}^{2}$ )}

Koefisieni determinasi $\left(\mathrm{R}^{2}\right)$ dipergunakan untuk mengetahui sampai seberapa besar persentase variasi variabel bebas padai model dapat menerangkan variasi pada variabel terikat. iKoefisien determinasi $\left(\mathrm{R}^{2}\right)$ dinyatakan dalam prosentase. Nilai $\mathrm{R}^{2}$ ini berkisari antara $0<\mathrm{R}^{2}<1$. Koefisien determinasi $\left(\mathrm{R}^{2}\right)$ bernilai nol berarti variabel independen sama sekali tidak berpengaruh terhadap variabel dependen. Apabila koefisien determinasi semakin mendekati satu, maka dapat dikatakan bahwa model independen berpengaruhi terhadap variabeli dependen semakin baik. Selain itu koefisien determinasi dipergunakan untuk mengetahui presentase perubahan variabel terikat ( $\mathrm{Y}$ ) yang disebabkan oleh variabel bebas $(\mathrm{X})$. Nilai koefisienideterminasi dapat dilihat dalam tabel berikut :

Tabel 2

Hasil Uji Determinasi ( $\mathbf{R}^{2}$ )

Model Summaryb

\begin{tabular}{lcccc}
\hline \multicolumn{1}{c}{ Variabeli } & Ri & R Squarei & $\begin{array}{c}\text { Adjusted R } \\
\text { Squarei }\end{array}$ & $\begin{array}{c}\text { Std. Error of the } \\
\text { Estimatei }\end{array}$ \\
\hline ADD (X1) &, $201 \mathrm{a}$ &, 040 &, 035 & 2900,446 \\
\hline Jumlah Wajibi Pajak (X2) &, $633 \mathrm{a}$ &, 400 &, 397 & 2292,361 \\
\hline Jumlah Penduduki (X3) &, $550 \mathrm{a}$ &, 302 &, 298 & 2473,011 \\
\hline Luas Lahani (X4) &, $586 \mathrm{a}$ &, 344 &, 340 & 2398,555 \\
\hline Sum
\end{tabular}

Sumber : Hasil Pengolahan SPSS v 21 (Data diolah 2019)

Dari tampilan SPSS model summary pada tabel 4.9 besarnya R Square adalah 0,040 hal ini berarti 4\% variabel dapati dijelaskan oleh ADDi (Alokasi Dana Desa) sedangkan sisanya sebesar $(100 \%-4 \%=96 \%)$ idijelaskan oleh variabel lainnya. Standart Error Of Estimate (SEE) sebesar 2900,446 semakin kecil nilai SEE akan membuat model regresi semakin tepat dalam memprediksi variabel dependen. Besarnya R Square untuki jumlah wajib pajak adalah 0,400 hal ini berarti $40 \%$ variabel dapat 
dijelaskan olehi jumlah wajib pajak sedangkan sisanya sebesar $(100 \%-40 \%=60 \%)$ dijelaskan oleh variabeli lainnya. iStandart Error Of Estimate (SEE) sebesar 2900,446 semakin kecil nilai SEE akan membuat model regresi semakin tepat dalam memprediksi variabel dependen.

Besarnya R Square untuk jumlah penduduki adalah 0,302 hal ini berarti 30,2\% variabel dapat dijelaskan oleh jumlah penduduk isedangkan sisanya sebesar (100\% $30,2 \%=69,8 \%$ ) dijelaskan oleh variabel lainnya. iStandart Error Of Estimate (SEE) sebesar 2473,011semakin kecil nilai SEE akan membuat model regresi isemakin tepat dalam memprediksi variabel dependen. iSerta Besarnya R Square untuk R Squarei Luas Lahan adalah 0,344 hal ini berarti 34,4\% variabel dapat dijelaskan oleh luas lahan sedangkan sisanya sebesar $(100 \%-34,4 \%=65,6 \%)$ idijelaskan oleh variabel lainnya. Standart Error Of Estimate (SEE) sebesar 2398,555 isemakin kecil nilai SEE akan membuat model regresi semakin tepat dalam imemprediksi variabel dependen.

\section{PEMBAHASAN}

\section{Alokasi Dana Desa berdampak terhadap Realisasi Penerimaan PBB-P2}

Alokasi dana desa yang biasa disebut ADD merupakan wujud dari pemenuhan hak desa untuk menyelenggarakan otonominya agar tumbuh dan berkembang mengikuti pertumbuhan dari desa itu sendiri, berdasarkan keanekaragaman, partisipasi, otonomi asli dan pemberdayaan masyarakat. Bantuan langsung ADD adalah dana bantuan langsung yang dialokasikan kepada pemerintah desa digunakan untuk meningkatkan sarana pelayanan masyarakat, kelembagaan dan prasarana desa yang diperlukan serta diprioritaskan oleh masyarakat, yang pemanfaatan dan administrasi pengelolaannya dilakukan dan dipertanggungjawabkan oleh kepala desa.

Pada hasil uji statistik menunjukkani bahwa Alokasi Dana Desa (ADD) berdampak terhadap Realisasi penerimaan PBB-P2. Hal ini ditunjukan bahwa nilai thitung lebih besar dari t-tabel $(2,769>1,97331)$ dengan tingkat signifikansi 0,006 . Artinya bahwa, ADD (Alokasi Dana Desa) berdampak terhadap penerimaan PBB-P2 karena t-hitung lebih besar dari t-tabel dan tingkat signifikansi imenunjukkan lebih kecil dari 0,05. Artinyai bahwa ADD berdampak signifikan terhadap penerimaan PBB-P2 di Kabupaten Jember. Sedangkan angka koefisien elastisitas ADD sebesar -4,047 berarti menunjukkani adanya pengaruh atau hubungan negatif antara Alokasi Dana Desai 
dengan penerimaani PBB-P2 di Kabupaten Jember. Angka elastisitas tersebut menunjukkan bahwa peningkatan jumlah wajib pajak Kabupaten Jember sebesar 1 persen, dengan asumsi variabel yang laini konstan, akani meningkatkan penerimaan PBB-P2 sebesar -4,047 persen. Sehingga peneliti menarik kesimpulan bahwa Ha diterima artinya Alokasi Dana Desa berdampak terhadap realisasi penerimaani PBB-P2 di Kabupaten Jember.

Hasil penelitian ini tidak konsisten dengan penelitian yang dilakukan Wawan (2017) bahwa alokasi dana desa tidak berpengaruh terhadap penerimaan PBB-P2 dan tidak memiliki pengaruh yang signifikan terhadap penerimaani PBB-P2. Hal tersebut menunjukan bahwa Alokasi Dana Desa yang dikeluarkan oleh pemerintah untuk desa sudah dikelola dengan baik sehingga masyarakat sudah merasakan manfaat dari penggunaan Alokasi Dana Desa yang diberikan oleh pemerintah provinsi untuk desa. Selain dari hal tersebut Alokasi Dana Desa yang digunakan sebesar 75\% sudah maksimal digunakan untuk pembangunan infrastruktur yang memadai sehingga pembangunan tersebut dapat meningkatkan kesejahteraan masyarakat untuk membayari PBB-P2.

Pemerintah Kabupaten Jember sempat mengeluarkan aturan dalam proses pencairan Alokasi Dana Desa harus disertai dengan bukti pelunasan Pajak Bumi dan Bangunan Pedesaan dan Perkotaan, namun aturan tersebut dihapuskan setelah dilakukan pembahasan kembali yang menghasilkan bahwa alokasi dana desa memiliki pengaruh secara langsung dengan Pajak Bumi dan Bangunan”, berdasarkan hal tersebut maka aturan yang mengharuskan dilampirknnya bukti pelunasan PBB P2 dalam hal pencairan dana ADD dihapuskan.

\section{Jumlah Wajib Pajak berdampak terhadap Realisasi Penerimaan PBB-P2}

Wajib pajak adalah orang pribadi atau badan yang meliputi pembayar pajak, pemotong pajak dan pemungut pajak yang mempunyai hak dan kewajiban perpajakan sesuai dengan ketentuan dan juga peraturan perundang-undangan perpajakan daerah yang berlaku di daerah tersebut. Pertumbuhan penduduk merupakan unsurpenting yang dapat memacu pertumbuhan ekonomi suatu wilayah. Pada hasil uji statistik menunjukkan bahwa jumlah wajib pajak berdampak terhadap Realisasi penerimaan PBB-P2. Hal ini ditujukan bahwa nilai t-hitung lebih besar dari t-tabel (11,056 > 
1,97331) dengan tingkat signifikansi 0,000. Artinya bahwa jumlah wajib pajak berdampak signifikan terhadap penerimaan PBB-P2. Angka koefisien elastisitasi jumlah wajib pajak sebesar 97,099 berarti menunjukkan adanya dampak positif antara jumlahiwajib pajak dengan penerimaan PBB-P2idiiKabupaten Jember. Angkaielastisitas tersebut menunjukkan bahwa peningkatan jumlah wajib pajak Kabupaten Jember sebesar 1 persen, dengani asumsi variabeliyang lain konstan, akani meningkatkan penerimaan PBB-P2 sebesar 97,099 persen. Sehingga peneliti menarik kesimpulan bahwa Ha2 diterima yang artinya jumlah wajib pajak berdampak terhadap realisasi penerimaan PBB-P2 di Kabupaten Jember.

Hasil penelitian ini konsisteni dengan penelitian yang dilakukan Sasana (2005) dan Febrianti (2017) yaitu jumlah wajib pajak memiliki pengaruh yang signifikan terhadap penerimaan PBB-P2. Kesadaran wajib pajak di Kabupaten Jemberi untuk membayar PBB-P2 ternyata cukup tinggi, dan berdampak positif dengan semakin meningkatnya penerimaan PBB-P2. Hal ini juga tidak terlepas dari pengaruh ketaatan masyarakati Kabupaten Jember yang lebih banyak tinggal di pedesaan dalam membayar PBB-P2.

\section{Jumlah Penduduk berdampak terhadapiRealisasi Penerimaan PBB-P2}

Pertumbuhani penduduk merupakan unsur penting yang dapat memacu pertumbuhan ekonomi suatu daerah. Penduduk yang besar akan menggerakkani berbagai kegiatan ekonomi dan merangsang tingkat output ataui produksi agregat yang lebih tinggi serta padaiakhirnya mendorong pertumbuhan ekonomi dan pendapatan nasional, yang berpengaruh pula terhadapipeningkatan penerimaan Pajak Bumi dan Bangunan Perdesaan dan Perkotaan.

Pada hasil uji statistik menunjukkan bahwa jumlah penduduk berdampak terhadap realisasi penerimaan PBB-P2. Hal ini ditujukani bahwa nilai t-hitung lebih besar dari t-tabel $(9,788>1,97331)$ dengan tingkat signifikansi 0.000 . Artinyai bahwa jumlah penduduk berdampak signifikan terhadap penerimaan PBB-P2 karena tingkat signifikansi lebih kecil dari 0,05i. Angkai koefisieni elastisitas jumlah penduduk sebesar 8,844 berarti menunjukkani adanya dampak positif antara jumlah penduduk dengan penerimaan PBB-P2 di Kabupaten Jember. Angka elastisitas tersebut menunjukkan bahwa peningkatan jumlah penduduk Kabupaten Jember sebesar 1 persen, dengan 
asumsi variabel yang lain konstan, akan meningkatkan penerimaan PBB-P2 sebesar 8,844 persen. Jumlah penduduk di Kabupaten Jemberi untuk membayar PBB-P2 ternyata cukup tinggi dan berdampak positif terhadap realisasi penerimaan PBB-P2. Sehingga peneliti menarik kesimpulani bahwa Ha3 diterima yang artinya jumlah wajib pajak berdampak terhadap realisasi penerimaan PBB-P2 di Kabupaten Jember.

Hasil penelitian tersebut sejalan dengan penelitian yang dilakukan Wawan (2017) dan Febrianti (2017) bahwa dalam penelitiannya menunjukan bahwa jumlah penduduk berpengaruh positif dan signifikani terhadap penerimaan PBB. Jumlah penduduk bisa tetap ditangani dengan serius, agar seiring bertambahnya jumlah penduduk, bertambahijuga wajib pajak yang membayar Pajak Bumi dan Bangunan dengan peningkatan kualitasisumber daya manusia di Kabupaten Jember. Jumlah penduduk tidak hanya menjadi beban di daerah Kabupaten Jember tetapi penduduk yang sebelumnya belum menjadi wajib pajak dapat berubah status menjadi wajib pajak. Penduduk yang besar akan menggerakkan berbagai kegiatan ekonomi dan merangsang tingkat outputiatau produksi agregat yang lebih tinggi yang pada akhirnya mendorong pertumbuhan ekonomi dan pendapatan nasional, yang berpengaruh pula terhadap peningkatan penerimaan pajak bumi dan bangunan.

\section{Luas Lahan (X4) berdampak terhadap Realisasi Penerimaan PBB-P2}

Berdasarkani data yang diperoleh dalam penelitian ini, Desa yang memiliki luas lahan yang paling tinggi yaitu Desa Ampel yaitu seluas 16,061.000 Km2, sedangkan Desa yang memiliki luas lahan yang paling rendah yaitu Desa Balung Kidul yaitu seluas 1,990.000 Km2. Rata-rata luas lahan yang dimiliki Kabupaten Jember tahun 2011-2015 yaitu seluasi 7,000,000,000 Km2.

Pada hasil uji statistik luas lahan berdampak terhadap realisasi penerimaan PBB-P2. Hal ini ditujukan bahwa nilai t-hitung lebih besar dari t-tabel $(9,788>$ 1,97331) dengan tingkat signifikansii 0.000. Artinya bahwa luas lahan berdampak sinifikan terhadap penerimaan PBB-P2 karena tingkat signifikansi lebih kecil dari 0,05. Angka koefisien elastisitas luas lahan sebesar 2918,544 berarti menunjukkan adanya dampak positif antara luas lahan dengani penerimaan PBB-P2 di Kabupaten Jember. Angka elastisitas tersebut menunjukkan bahwa peningkatan luas lahan perdesa Kabupaten Jember sebesar 1 persen, dengani asumsi variabel yang lain konstan, akan 
meningkatkan penerimaan PBB-P2 sebesar 2918,544 persen. Luas lahan di Kabupaten Jember memili potensi yang cukup besar sebagai sumber objek dari Pajak PBB-P2, sehinggai peneliti menarik kesimpulan bahwa Ha4 diterima yang artinya jumlah wajib pajak berdampak terhadap realisasi penerimaan PBB-P2idiiKabupaten Jember.

Hasil penelitian ini sejalan dengani penelitian yang dilakukan Sasana (2005), Wawan (2017) dan Hasniar (2014) bahwai dalam penelitiannya menunjukan bahwa luas lahan berpengaruh positif dan signifikan terhadap penerimaan PBB. Semakin besar luas lahani yang dimiliki, semakin tinggi pula pendapatan yang diperoleh, dan pada akhirnya akan menambah kemampuan merekai untuk membayar PBB. Dengan demikian, setiap penambahan luas lahan yang dimanfaatkan masyarakat selain akan menambah jumlah wajib pajak baru, tentunya juga akan menaikkan pendapatan per kapita masyarakat sehingga akan meningkatkan penerimaan PBB.

\section{SIMPULAN}

Berdasarkani analisis dan hasil uji hipotesis yang telah dilakukan pada penelitian ini, maka ditarik kesimpulan sebagai berikut; 1) alokasi dana desa secara parsial berdampak signifikan terhadap realisasii penerimaan PBB-P2; 2) jumlah wajib pajak berdampak signifikan terhadap realisasii penerimaan PBB-P2 3) jumlah penduduk berdampak signifikan terhadap realisasii penerimaan PBB-P2; 4) luas lahan berdampak signifikan terhadap realisasi penerimaan PBB-P2i

\section{DAFTAR PUSTAKA}

Abdullah, R. (2007). Pelaksanaan Otonomi Luas dengan Pemilihan Kepala Daerah secara Langsung. Jakarta: Raja Grafindo.

Aljannah, S., Syafril, B., \& Indri. (2016). Evaluasi Alokasi Dana Desa (ADD) dalam Menunjang Pembangunan Desa di Kecamatan Tambusai Utara Kabupaten Rokan Hulu (Studi Kasus: Desa Tambusai Utara Tahun 2013-2014). Jurnal Online Mahasiswa (JOM) Bidang Ilmu Ekonomi (4)1.

Febrianti, M. (2017). Faktor-Faktor yang Mempengaruhi Realisasi Penerimaan Pajak Bumi dan Bangunan Sektor Pedesaan dan Perkotaan di Kabupaten Bangka Tengah. Tesis. STIE Trisakti.

Hasniar. (2016). Faktor-faktor yang Mempengaruhi Penerimaan Pajak Bumi dan Bangunan $(P B B)$ di Kebupaten Bone. Disertasi. Universitas Islam Negeri Alauddin. Makassar. 
Imam, C. (2009). Manajemen Sumber Daya Manusia Strategik. Yogyakarta: Penerbit Amus.

Rahman, A. (2011). Panduan Administrasi Perpajakan. Bandung: Penerbit Nuansa Cendikia.

Rahmawati F. (2008). Desentralisasi Fiskal: Konsep. Hambatan dan Prospek dalam Desentralisasi Ekonomi di Indonesia. Kajian Teoritis dan Realitas Empiris. Skripsi. Universitas Brawijaya. Malang: Bayumedia Publishing.

Sasana. H. (2005). Analisis Faktor-Faktor yang Mempengaruhi Penerimaan Pajak Bumi dan Bangunan (PBB) Studi Kasus di Kabupaten Banyumas. Jurnal Dinamika Pembangunan (2)1: 19-29

Wawan. A. (2017). Pengaruh Alokasi Dana Desa, Jumlah Penduduk dan Luas Lahan terhadap Realisasi Penerimaan PBB-P2 Kabupaten Sigi. Katalogis 5.5. Tesis. Universitas Tadulako. 